$\$=1$ 圆

\title{
The Effect of Prolonged Irrigation on the Dry Steppe Soils' Fertility in the Volga Region
}

\author{
Nina Anatolyevna Pronko ${ }^{1}$, Viktor Vladislavovich Korsak ${ }^{1}$, Lubov Gennadievna Romanova ${ }^{1}$, Aleksey \\ Vladimirovich Kravchuk ${ }^{1}$, Vladimir Viktorovich Afonin ${ }^{1}$
}

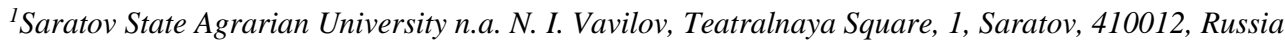

\begin{abstract}
The article deals with the negative effect of the prolonged irrigation on the contents and quality of humus, and plant nutrients' stock in the soil. The research was aimed at studying the nature and regularities of the transformation of organic matter (humus) and nutrients in the dark chestnut soil of dry steppe zone in the Volga region in the process of irrigation over half a century long. Field and laboratory experiments, as well as theoretical methods, such as mathematical statistics were used for studying the soil agrochemical properties. The research has shown that humus mineralization in irrigated soils is more pronounced, compared to nonirrigated soils, dehumification increases with increasing the period of irrigation and intensification of agriculture; the content and stock of humus decreases with irrigation, and is accompanied by the negative changes in its qualitative composition. The article describes the reasons for dehumification and negative changes in the qualitative composition of humus in the dark chestnut soils: deficient nitrogen balance due to insufficient use of nitrogen fertilizers, which resulted in the destruction of the organic matter in the soil, increased share of tilled crops in the crop structure, absence of nitrogen-fixing ability in alfalfa due to significant soil compaction, and insufficient introduction of organic fertilizers. The found peculiarities of dehumification and reduction of nutrients availability in the soil, which are the most dangerous degradation processes in the soils of the region that reduce the efficiency of irrigated agriculture, are required for developing substantiated solutions for preventing dehumification, restoring the fertility of irrigated soils, and reducing deficiency of foodstuffs in arid regions.
\end{abstract}

Keywords: Humus, Soil Nutrients, Irrigation, Transformation Of Humus And Nutrients In The Soil.

\section{Introduction}

The most important problem in the world is the increased food deficiency. The solution to this problem requires a significant increase in crop production. In arid areas, this cannot be achieved without expanding irrigation areas, since irrigation has always been and remains an important factor that influences agricultural productivity [1-4]. However, irrigation contributed to widely spread degradation of irrigated agricultural lands. Along with salinization and waterlogging of soils [5-8], irrigation increased their dehumification, and reduced the available nutrients in the soils. In Russia, the average humus losses over the last 15 years in not washed-off soils have been $9.5 \%$, and the annual average values have been $0.62 \mathrm{t} / \mathrm{ha}$. In the Saratov region, humus losses over the last 20 years have achieved $6-16 \%$, with the average annual humus balance deficiency of $0.59-0.91 \mathrm{t} / \mathrm{ha}$. Soil dehumification is an extremely undesirable process. It is determined by the enormously important role of humus in soil fertility, as it is a universal system that determines and regulates the level of almost all factors that contribute to increasing or decreasing soil fertility [9]. Well humified soils are characterized by a strongly pronounced phytosanitary ability, which ensures the cultivation of environmentally clean products; these soils are less prone to the effect of artificial rain, which destroys the structure and compacts the soils.

To reduce the foodstuffs' shortage, it is necessary to know the nature of the organic matter and nutrients' transformation processes that occur in case of long-term irrigation of dark-chestnut soils in the dry steppes in the Volga region, which constitute the majority of irrigated lands in the region, as well as the reasons for these processes.

\section{Literature review}

The importance of preserving organic matter in the soil has been long understood in agricultural science. As early as in the XIX century, the founder of Russian Soil Science V. V. Dokuchaev pointed to the direct correlation between the soil fertility and the content of humus in it [10]. In the United States, in the thirties of the last century W. L. Powas and R. D. Lewis studied the regularities of the effect of nitrogen and organic matter in the soil on its productivity [11], Wm. A. Albrecht - the loss of organic matter in the soil [12], W. L. Powers - the characteristics of organic soil colloids [13], and R. M. Salter and T. C. Green - the factors of organic carbon accumulation and loss [14]. Works of N.A. Tuev [15] were of great importance for understanding the processes of humus substances' formation and decomposition in the soil. Currently, the specific problems of soil dehumification at irrigated farmlands in the Russian Federation and in the neighboring countries are widely studied. Human-induced changes in the organic matter of the dark chestnut soils of Northern Kazakhstan were studied by A. K. Kurishbayev et al [16], the current humic condition of the irrigated meadow-brown soils in the Republic of Armenia - by H. Gh. Ghazaryan et al. [17], changes in the conditions of humus formation in the typical black soils of the Northern part of the Republic of Moldova under the influence of irrigation were studied by I. Senikovskaya and V. Filipchiuk [18], the content of organic carbon, total nitrogen and dissolved 
fractions of soil organic matter in the Chersky meadows (Republic of Poland) in the conditions of long-term irrigation (over 150 years) — by A. Dziamski, M. Banach-Szott, B. Dębska [19], changes in the structure of humus and microbial cenoses in deflated chestnut soils of Western Transbaikalia - by M. G. Merkusheva and S. B. Sosorova [20], and the content of humus in the long irrigated soils of the Akdalinsky and Chiiliysky massifs in the southern Kazakhstan - by M. A. Ibraeva, A. Otarov, B. Wiłkomirski, M. Suska-Malawska [21].

\section{Methods and materials}

The research was performed at the agricultural enterprises representative for the irrigated agriculture in the steppe zone of the Volga region: ZAO Agrofirm "Volga" in the Marx district, development and production facilities of the Volga Scientific Research Institute of Hydraulic Engineering and Land Reclamation (OPH VolzNIIGiM) in the Engels district, and the Ershovka Experimental Land Reclamation Station (Ershovka OMS) in the Ershovka district of the Saratov region. Representativeness was assessed by the collection of indicators: soil and climate - typical for the irrigation in the dry steppe zone of the region, irrigation with water from the Volga River with hydrocarbonate-calcium salinity of $0.2-0.3 \mathrm{~g} / \mathrm{l}$, through the engineering irrigation systems with the use of the most common method of irrigation - sprinkling irrigation, prolonged irrigation duration $-35,60$, and 65 years. Field and laboratory experiments, as well as theoretical methods, such as mathematical statistics were used for studying the agrochemical properties of the soil. The research was performed from 1990 to 2010. To determine the nature of organic matter and nutrients' transformation in the soil under the influence of continuous irrigation, archive materials of the state agrochemical station Saratovskaya of the Volga Research Institute of Hydraulic Engineering and Land Reclamation and of the Ershovskaya Experimental Land Reclamation Station were used [22-26]. Field experiments were performed in accordance with the commonly adopted methods. Soil samples were selected according to the Methodical guidelines on comprehensive monitoring of agricultural soil fertility (2003). The content of humus was determined using the method of I. V. Turin (GOST 26213-84). The data were analyzed using the methods of correlation and regression analysis according to B. A. Dospekhov, using the STATISTICA 5.5 software and Microsoft Excel spreadsheet editor.

\section{Results and discussion}

The results have shown that in the process of long-term irrigation, the content of humus in the irrigated dark chestnut soils reduces (Table 1, Figure 1).

Table 1: Changes in the content of humus in the topsoil of the irrigated dark chestnut soil in the dry steppe zone of the Volga region, \%

\begin{tabular}{|c|c|c|c|c|c|c|c|}
\hline \multicolumn{8}{|c|}{$\begin{array}{l}\text { Experimental production farm of the Volga Scientific Research Institute } \\
\text { of Hydraulic Engineering and Land Reclamation in the Engels district } \\
\text { of the Saratov region }\end{array}$} \\
\hline Year & 1950 & 1960 & 1970 & 1980 & 1993 & 1996 & 2008 \\
\hline $\begin{array}{l}\% \text { of } \\
\text { humus }\end{array}$ & 3.80 & 3.75 & 3.59 & 2.90 & 2.84 & 2.77 & 2.80 \\
\hline \multicolumn{8}{|c|}{ ZAO Agrofirm "Volga", Marx district of the Saratov region } \\
\hline Year & 1990 & & & 2001 & 2004 & & 2006 \\
\hline $\begin{array}{l}\% \text { of } \\
\text { humus }\end{array}$ & 3.05 & & & 2.96 & 2.92 & & 2.88 \\
\hline \multicolumn{8}{|c|}{$\begin{array}{l}\text { Ershovka Experimental Land Reclamation Station } \\
\text { Ershovka district of the Saratov region }\end{array}$} \\
\hline Year & 1954 & & & 1980 & 1994 & & 2004 \\
\hline $\begin{array}{l}\% \text { of } \\
\text { humus }\end{array}$ & 3.55 & & & 3.00 & 2.92 & & 2.72 \\
\hline
\end{tabular}

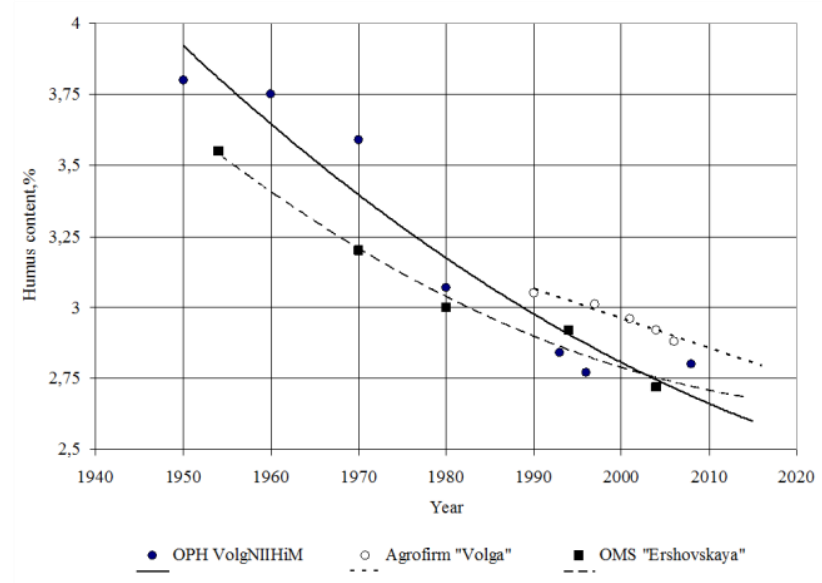

Fig. 1: Trends in the changes in the content of humus in the topsoil of the irrigated dark chestnut soil in the dry steppe zone of the Volga region

In the soils of the experimental production farm of VolzNIIGiM, humus content decreased from $3.80 \%$ in 1950 to $2.80 \%$ in 2008 (by $26.32 \%$ over almost 60 years); of ZAO Agrofirm "Volga" from $3.05 \%$ in 1990 to $2.88 \%$ in 2006 (by $5.57 \%$ over 16 years); and of Ershovka Experimental Land Reclamation Station - from $3.55 \%$ in 1954 to $2.72 \%$ in 2004 (by $23.38 \%$ over 50 years). These data show that the longer is the period of using the irrigated lands, the more pronounced is the process of irrigated dark chestnut soils dehumification.

Calculations show that over the years of observation, the content of humus had annually decreased in the soils of experimental production farm VolzNIIGiM by 0.02 absolute \%, ZAO Agrofirm "Volga" - by 0.01 absolute $\%$. The rate of soil dehumification at the experimental production farm of VolzNIIGiM had varied considerably over the 60 -year period. Over the first 20 years, the content of humus was decreasing on the average at the rate of 0.01 $\%$ per year. In the subsequent years, the decrease rate increased over 5 times.

The trends of changes are expressed by the following mathematical equations (Gum - content of humus, \%; Year - year number):

Gum $=0.0001 \cdot$ Year $^{2}-0.5365 \cdot$ Year +555.12 for the experimental production farm of VolzNIIGiM;

Gum $=-0.0104 \cdot$ Year +23.28 for ZAO Agrofirm "Volga";

Gum $=0.0001 \cdot$ Year $^{2}-0.6075 \cdot$ Year +619.73 for the Ershovka Experimental Land Reclamation Station.

The levels of approximation reliability $\left(\mathrm{R}^{2}\right)$ for these equations were $0.9205,0.9476$, and 0.9812 , respectively.

The main reason for dehumification of the irrigated dark chestnut soils was the intensification of irrigated agriculture with insufficient intake of fresh organic matter. Thus, at the experimental production farm of VolzNIIGiM, intensification of the technologies of agricultural crops' cultivation, especially the use of high-yielding varieties and the use of pesticides, contributed to 2.9 times growth of spring wheat yield; 3.1 times - for winter wheat, and 1.25 times - for maize. As a result, the total subtraction of nitrogen by cultivated crops had increased 1.94 times from the 50 -ies to the 80 ies, which was the reason for the deficient balance of humus on the background of the almost twofold decrease of organic fertilizers' introduction. Along with the increased nitrogen subtraction, the increased share of tilled crops from 12 to $50 \%$, and the loss by alfalfa of its nitrogen-fixing ability due to soil compaction to 1.5 $1.57 \mathrm{~g} / \mathrm{cm}^{3}$ played their roles $[9,26]$.

The process of humus mineralization in the irrigated lands is more pronounced, compared to the nonirrigated ones. Thus, over the 20 years from 1964 to 1984, the content of humus in the irrigated dark chestnut soils at the experimental production farm of VolzNIIGiM had decreased by $1 \%$, while in the nonirrigated conditions, the content of humus in this subtype of soils on the average for the Saratov region had decreased by $0.7 \%$.

The calculation of humus balance for 1997-2006 in the soil of 18 irrigated fields of ZAO Agrofirm "Volga" with the area of about 
2,000 hectares has shown that for most of them (13 of 18) it was deficient, and the average value of the deficiency amounted to $5 \mathrm{t} / \mathrm{ha}$ (Figure 2).

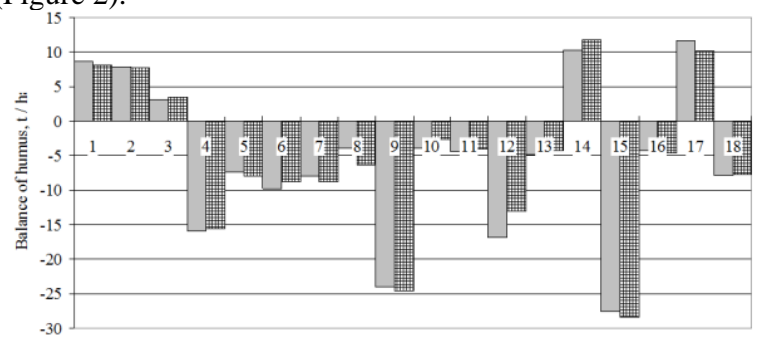

$\square$ Estimated 田 Actual

Fig. 2: Estimated and actual humus balance in the dark chestnut soil of individually irrigated fields of ZAO Agrofirm "Volga" in the Marx district of the Saratov region

The mean-square deviation between the estimated and the actual value amounted to $1.33 \mathrm{t} / \mathrm{ha}$, which was within the analytical precision for determination of humus content. The correlation coefficient was $\mathrm{R}=0.95$. The Fisher LSD is $\mathrm{F}=1.01$ with the tabular $\mathrm{F}_{05}=2.29$, and $\mathrm{t}$-test is $\mathrm{t}=1.7$ with the tabular $\mathrm{t}_{05}=2.11$, which proves the validity of the null hypothesis, and, therefore, the accuracy of the calculations.

Simultaneously with the depletion of reserves and the decreasing content of humus in the irrigated dark-chestnut soils of the dry steppe in the Volga region, some negative changes occurred in the quality of humic substances, especially in the conditions of high rising groundwater (Table 2).

Table 2: Humus fractional composition in the arable layers of dark-chestnut soils at the Ershovka experiment station (\% of $\left.\mathrm{C}_{\text {total }}\right)$

\begin{tabular}{|c|c|c|c|c|c|c|c|c|c|c|}
\hline \multicolumn{4}{|c|}{ Humic acids } & \multicolumn{5}{|c|}{ Fulvic acids } & \multirow[b]{2}{*}{$\begin{array}{l}\text { Nonhydrolyzed } \\
\text { residue }\end{array}$} & \multirow[b]{2}{*}{$\mathrm{Cha} / \mathrm{Cfa}$} \\
\hline $\begin{array}{l}\text { free } \\
\text { (HA1) }\end{array}$ & $\begin{array}{l}\text { bound } \\
\text { with Ca } \\
\text { (HA2) }\end{array}$ & $\begin{array}{l}\text { tightly } \\
\text { bound } \\
\text { (HA3) }\end{array}$ & Total & $\begin{array}{l}\text { aggressive } \\
\text { (FA1a) }\end{array}$ & $\begin{array}{l}\text { bound } \\
\text { with } \\
\text { HA1 } \\
\text { (FA1) }\end{array}$ & $\begin{array}{l}\text { bound } \\
\text { with HA2 } \\
\text { (FA2) }\end{array}$ & $\begin{array}{l}\text { tightly } \\
\text { bound } \\
\text { (FA3) }\end{array}$ & Total & & \\
\hline \multicolumn{11}{|c|}{ Irrigated plot 1 , groundwater level less than $2 \mathrm{~m}$} \\
\hline 6.6 & 18.1 & 9.4 & 34.1 & 3.1 & 1.3 & 8.1 & 4.4 & 16.9 & 49.0 & 2.0 \\
\hline \multicolumn{11}{|c|}{ Irrigated plot 2, groundwater level more than $10 \mathrm{~m}$} \\
\hline 5.5 & 15.7 & 8.2 & 29.4 & 3.4 & 1.4 & 7.5 & 3.9 & 16.2 & 54.6 & 1.8 \\
\hline \multicolumn{11}{|c|}{ Plot 3, without irrigation } \\
\hline 1.9 & 20.5 & 8.6 & 31.0 & 3.3 & 1.3 & 9.3 & 3.9 & 17.8 & 51.2 & 1.7 \\
\hline
\end{tabular}

The comparative analysis of humus qualitative composition in the soils of irrigated and nonirrigated plots has shown that, compared to bogharic lands, the amount of mobile organic substances had increased, which resulted in the intensification of the losses of organic matter in the soil due to its removal into the second halfmeter of the soil layer. The content of humic acids bound with calcium also decreased (especially in the irrigated soils with the automorphic type water regime).

The trends in the changes in the content of main plant nutrients were also negative, especially those of available phosphorus and exchange potassium in the irrigated dark chestnut soils of the dry steppe zone of the Volga region. Due to the insufficient introduction of phosphatic and potash fertilizers, deficiency of these nutrients occurred.

Calculation of phosphorus balance for 1997-2006 (Figure 3) showed that it had been deficient for all 17 studied arable fields of ZAO Agrofirm "Volga". The balance of exchange potassium was also deficient for almost all studied fields (Figure 4).

The deficient balances cause expressed processes of reducing the content of available phosphorus and exchangeable potassium (Table 3).

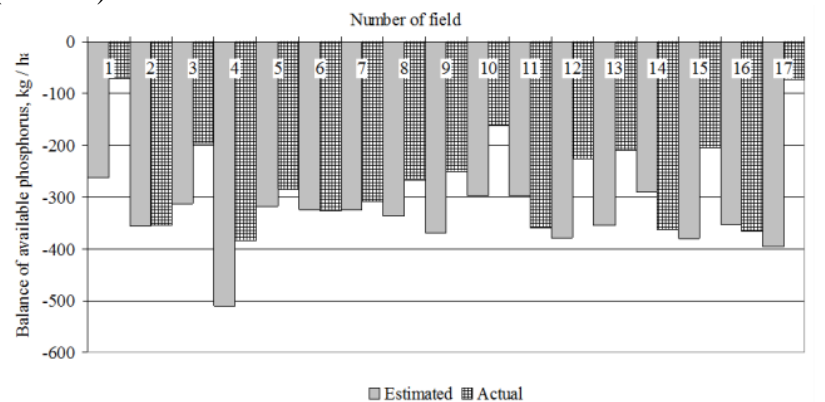

Fig. 3: Estimated and actual available phosphorus balance in the dark chestnut soil of individually irrigated fields of ZAO Agrofirm "Volga" in the Marx district of the Saratov region

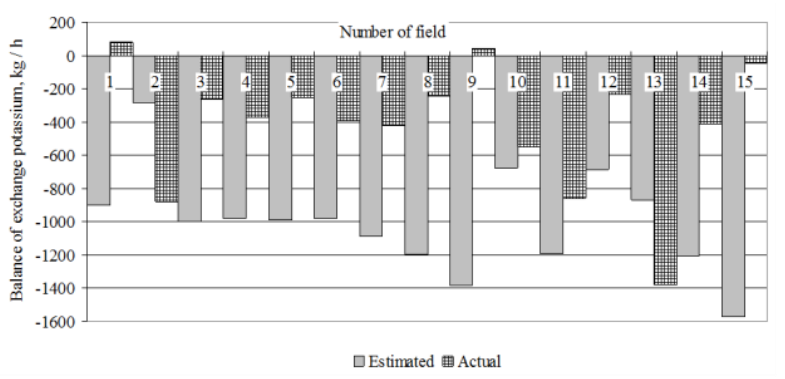

Fig. 4: Estimated and actual exchange potassium balance in the dark chestnut soil of individually irrigated fields of ZAO Agrofirm "Volga" in the Marx district of the Saratov region

Table 3: Changes in the content of main plant nutrients in the arable layers of irrigated dark chestnut soils at ZAO Agrofirm "Volga", mg per $100 \mathrm{~g}$ of soil

\begin{tabular}{|l|l|l|l|l|l|l|}
\hline \multirow{2}{*}{ Year } & \multicolumn{4}{|l|}{ Available phosphorus } & \multicolumn{3}{l|}{ Exchange potassium } \\
\cline { 2 - 7 } & Average & Min & Max & Average & Min & Max \\
\hline 1997 & 9.70 & 2.60 & 17.2 & 35.93 & 13.20 & 65.60 \\
\hline 2001 & 8.90 & 2.30 & 14.30 & 39.49 & 10.60 & 80.00 \\
\hline 2004 & 3.50 & 1.00 & 6.10 & 24.22 & 8.53 & 58.73 \\
\hline 2006 & 3.27 & 1.67 & 5.85 & 31.64 & 22.00 & 57.50 \\
\hline
\end{tabular}

As a result, a decreased content of available forms of phosphorus was noted in the soil of $72 \%$ of the irrigated fields at ZAO Agrofirm "Volga". With that, in $16 \%$ of the fields there was a very strong reduction in phosphorus content with the change of reserves' group from the fifth (very high reserve level) to the second (low reserve level), and even the first (very low reserve level). A $66 \%$ decrease in the content of exchange potassium was noted. With that, in $22 \%$ of the fields there was a very strong reduction in $\mathrm{K}_{2} \mathrm{O}$ content with the change of reserves' group from the third (moderate reserve level) to the second (low reserve level), and even the first (very low reserve level).

\section{Conclusion}

During the crop production on the dark chestnut soils of the dry steppe zone of the Volga region, sprinkler irrigation results in the 
transformation of their organic matter and nutrients, which is characterized by the following peculiarities:

- with increasing the period of irrigation and with the growth of irrigated agriculture intensification, the process of dehumification intensifies;

- the main reasons for soil dehumification are the following: deficient balance of humus and nitrogen due to the insufficient introduction of organic and nitrogen fertilizers, increased share of tilled crops and loss of alfalfa's ability to fix nitrogen due to soil compaction;

- the process of humus mineralization under irrigation is more pronounced, compared to bogharic lands;

- reduction of the humus content under irrigation is accompanied by negative changes in its qualitative composition; and

- the process of decreasing the reserve of available nutrients in the soils due to the deficiency of their balance due to the insufficient introduction of phosphate and potash fertilizers is pronounced.

\section{References}

[1] Cunningham WP, Cunningham MA (2010), Environmental science: a global concern, New York: McGraw Hill Co., 11th ed., 618.

[2] Doklad o sostoianii i ispol zovanii zemel sel skokhoziaistvennogo naznacheniia [A report about the state and the use of agricultural land]. Moscow: Ministry of Agriculture of the Russian Federation, 2013, 66.

[3] Ovchinnikov AS, Bubenchikov MM, Pakhomov AA (2011), The state and prospects of reclamation development in the Volgograd area, Environmental engineering, 4, 12-15.

[4] Scherr SJ (1999), Soil Degradation. A Threat to Developing-Country Food Security by 2020?, Washington, U.S.A.: International Food Policy Research Institute, 63.

[5] Le, QB, Nkonya E, Mirzabaev A (2014), Biomass ProductivityBased Mapping of Global Land Degradation Hotspots, ZEFDiscussion Papers on Development Policy, 193. Bonn, 57.

[6] Nkonya E, von Braun J, Mirzabaev A, Le QB, Kwon HY, Kirui O (2013), Economics of Land Degradation Initiative: Methods and Approach for Global and National Assessments, ZEF-Discussion Papers on Development Policy, 183. Bonn, 41.

[7] Food and Agriculture Organization of the United Nations. www.fao.org.

[8] Abrol IP, Yadav JSP, Massoud FI (1988), Salt-Affected Soils and their Management, FAO Soils Bulletin, 39. Food And Agriculture Organization Of The United Nations. Rome.

[9] Pronko NA, Romanova LG, Falkovich AS (2005), Changes in the fertility of irrigated chestnut soils in the Volga region in the process of long use, and the scientific bases of its regulation, FSHEI HPE, Saratov SAU, 220

[10] Dokuchaev VV (1885), Russkii chernozem [Russian black earth] Popular essay, 18, $194-215$

[11] Powas WL, Lewis RD (1930) Nitrogen and organic matter as related to soil productivity. Jr. Am. Soc. Agron, 22(10), 825-832.

[12] Albrecht WmA (1938), Loss of soil organic matter and its restoration. U.S.D.A. Yearbook of Agriculture.

[13] Powers WL (1932), Characteristics of dispersable organic soil colloids. Tr. Agr. Research, 44(2), 97-111.

[14] Salter RM, Green TC (1933), Factors affecting the accumulation and loss of nitrogen and organic carbon in cropped soils. Jr. Am. Soc. Agron, 25(9), 622-630.

[15] Tuev NA (1989), Mikrobiologicheskie protsessy gumusoobrazovaniia [Microbiological processes of humus formation]. M: Agropromizdat, 239.

[16] Kurishbayev AK, Chernenok VG, Zvyagin GA (2016) Antropogenous Changes of Dark-Chestnut Soils of the Northern Kazakhstan and measures for their Improvement. IEJME Mathematics Education, 11(6), 1577-1590. http://www.iejme.com/download/antropogenous-changes-of-darkchestnut-soils-of-the-northern-kazakhstan-and-measures-fortheir.pdf

[17] Ghazaryan HGh, Kroyan SZ, Manukyan NM, Kalashian My (2016), Current state of humus in irrigated meadow-brown soils in the Republic of Armenia, Annals of Agrarian Science, 14(4), 307-310. https://doi.org/10.1016/j.aasci.2016.10.004

[18] Senikovskaya I, Filipchiuk V (2011), Effects of irrigation and amelioration technology on microbiological and enzymatic properties of soil. Scientific Papers, UASVM Bucharest, Series A LIV. ISSN 1222-5339;

[19] Dziamski A, Banach-Szott M, Debska B (2015), The effect of longterm irrigation of meadows on the state of organic matter. Acta Sci. Pol. Agricultura, 14(2), 15-27. www.agricultura.acta.utp.edu.pl

[20] Merkusheva MG, Sosorova SB (2013), Change of the Structure of Humus and Microbial Cenoses in Deflated Chestnut Soils. Natural Resources and Conservation, 1(1), 9-14. http://www.hrpub.org

[21] Ibraeva MA, Otarov A, Wiłkomirski B, Suska-Malawska M (2010), Humus level in soils of Southern Kazakhstan irrigated massifs and their statistical characteristics (Poziom humusu w glebach nawadnianych masywów południowego Kazachstanu charakterystyka statystyczna) Monitoring Środowiska Przyrodniczego, 11, 55-61. Kieleckie Towarzystwo Naukowe, Kielce.

[22] Antipov-Karataev IN (1940), Ob izmenenii osnovnykh khimicheskikh svoistv glavneishikh pochv Zavolzh ia pri oroshenii [About changes in the basic chemical properties of main soils of the Trans-Volga region under irrigation], Problems of the Soviet soil science. M.- L. AS USSR, 117 - 158 .

[23] Baranovskaya VA, Azovtsev VN, Okolelova AA (1989), O protsessakh transformatsii organicheskoi chasti pochvy Nizhnego Povolzh ia pri oroshenii [About the processes of soil organic part transformation in the Lower Volga region under irrigation], Increasing the fertility of irrigated soils under intensive use: Collection of scientific works, Volgograd, $79-86$.

[24] Gorelik LA (1968), Agrokhimicheskaia kharakteristika temnokashtanovykh terrasovykh pochv i effektivnost na nikh udobrenii v usloviiakh orosheniia [Agrochemical characteristic of the dark chestnut terraced soils and the efficiency of their fertilizers under irrigation]: Abstract of diss. ... candidate of agricultural Sciences. M 20.

[25] Kostin IS (1958), Tasks and some results of the Engels Experimental Land Reclamation Station of VNIIGiM. Collection of works of the Engels experimental land reclamation station of VNIIGiM, II. Saratov: Publishing house, pp. $3-21$.

[26] Pronko NA (1999), Agromeliorativnye osnovy proizvodstva $i$ avtomatizirovannaia tekhnologiia upravleniia vyrashchivaniem polevykh kultur na oroshaemykh zemliakh Povolzhia [Land reclamation basics of production and automated technology of controlling crops cultivation on the irrigated lands of the Volga region]: Abstract of diss. ... Doctor of Agricultural Sciences. Saratov, 52. 